\title{
Application of Classroom Management Principles and Their Effect on Student Motivation in Elementary School
}

\author{
Juniatul Ana Nurlita \\ SD Negeri Mangunlegi 01 \\ lita.beryl@gmail.com
}

\section{Article History}

received 3/12/2020

\begin{abstract}
This research is a qualitative descriptive study. The aim is to describe the application of classroom management principles and explain its effect on the learning motivation of grade 1 students at SDN Mangunlegi 01 Batangan. The participants of this study were 14 students and 1 teacher. The data analysis technique used in this research is interactive data analysis. Based on the analysis, it was concluded that classroom management at SDN Mangunlegi 01 Batangan was carried out properly in accordance with the principles of classroom management, namely: teacher attitudes such as enthusiasm, warmth, and intimacy. Challenging learning. Various learning activities. The flexibility of the teacher in every action. Positive instruction to students. Cultivate discipline in students. Through the implementation of classroom management, students become motivated and exhibit behaviors such as: Active in class. Willing to try hard things. Desire to study successfully. I want to start with myself. Persevere in the face of learning difficulties. Pay attention to the teacher. So it can be concluded that the principle of classroom management has an effect on students' learning motivation.
\end{abstract}

Keywords: classroom management, learning motivation, elementary school

\begin{abstract}
Abstrak
Penelitian ini merupakan penelitian deskriptif kualitatif. Tujuannya untuk mendeskripsikan penerapan prinsip pengelolaan kelas dan menjelaskan pengaruhnya terhadap motivasi belajar siswa kelas 1 SDN Mangunlegi 01 Batangan. Partisipan penelitian ini adalah 14 siswa dan 1 guru. Teknik analisis data yang digunakan dalam penelitian ini adalah analisis data interaktif. Berdasarkan analisis disimpulkan bahwa pengelolaan kelas di SDN Mangunlegi 01 Batangan dilaksanakan dengan baik sesuai dengan prinsip-prinsip pengelolaan kelas, yaitu: sikap guru seperti semangat, kehangatan, dan keakraban. Pembelajaran yang menantang. Berbagai kegiatan pembelajaran. Keluwesan guru dalam setiap tindakan. Instruksi positif pada siswa. Menumbuhkan kedisiplinan pada siswa. Melalui penerapan manajemen kelas, siswa menjadi termotivasi dan menunjukkan perilaku seperti: Aktif di kelas. Mau mencoba hal-hal yang sulit. Keinginan untuk belajar dengan sukses. Ingin memulai dari diri sendiri. Bertahan ketika menghadapi kesulitan belajar. Memperhatikan guru. Sehingga dapat disimpulkan bahwa prinsip pengelolaan kelas berpengaruh terhadap motivasi belajar siswa.
\end{abstract}

Kata kunci: manajemen kelas, motivasi belajar, sekolah dasar

Social, Humanities, and Education Studies (SHEs): Conference Series p-ISSN 2620-9284 https://jurnal.uns.ac.id/shes

e-ISSN 2620-9292 
SHEs: Conference Series 3 (4) (2020) 126-131

\section{PENDAHULUAN}

Menurut ilmu psikologi, motivasi merupakan suatu tingkah laku kompleks yang mempengaruhi individu untuk menekuni dan meluangkan waktu, tenaga, pikiran, serta perasaan dalam suatu kegiatan tertentu. Teori determinasi diri membedakam motivasi menjadi dua jenis, yaitu motivasi instrinsik dan motivasi ekstrinsik. Motivasi instrinsik merujuk pada perilaku seseorang yang diakibatkan adanya rasa ketertarikan terhadap sesauatu, sedangkan motivasi ekstrinsik merujuk pada alasan seseorang melakukan sesuatu yang bukan berasal dari adanya minat terhadap kegiatan tersebut.

Terkait dengan motivasi belajar, dapat disimpulkan bahwa motivasi belajar adalah dorongan dari dalam atau luar diri siswa yang memberikan penguatan, ketekunan, dan semangat untuk mencapai tujuan tertentu berupa perubahan atau penguatan tingkah laku. Motivasi belajar dapat didefinisikan sebagai suatu hal yang mendorong siswa untuk aktif dalam kegiatan akademis, mencoba hal-hal sulit, dan menentukan waktu yang disediakan untuk belajar. Pada bulan Agustus 2020, peneliti melakukan observasi di kelas 1 SDN Mangunlegi 01 Batangan. Hasil observasi menunjukkan bahwa pembelajaran masih belum berjalan kondusif. Siswa belum dapat aktif dan disiplin, beberapa siswa masih sering berbicara dengan teman dan tidak memperhatikan penjelasan guru. Hal itu menunjukkan bahwa motivasi siswa masih rendah. Siswa yang mengikuti pembelajaran idealnya memperhatikan dengan baik, mematuhi tata tertib, dan berpartisipasi aktif.

Pada tanggal 24 September 2020, peneliti melakukan wawancara terhadap salah satu guru kelas 1 SDN Mangunlegi 01 Batangan. Berdasarkan hasil wawancara, disimpulkan bahwa motivasi belajar siswa kelas 1 cukup tinggi, namun masih terdapat beberapa siswa dengan motivasi belajar yang rendah. Ketika memasuki jam ke-5, siswa mengalami penurunan motivasi belajar. Hal itu disebabkan oleh lama waktu belajar, beban belajar, kebosanan, dan sebagainya. Dalam wawancara tersebut, peneliti juga menanyakan bagaimana kondisi siswa pada awal tahun ajaran. Berdasarkan penuturan narasumber, kondisi siswa belum siap untuk menerima pembelajaran. Setelah libur panjang, siswa harus beradaptasi terlebih dahulu. Hal itu dikarekan selama liburan siswa jauh dari situasi dan aktivitas belajar seperti di sekolah. Dalam kondisi tersebut, peran motivasi belajar sangat penting. Motivasi belajar akan merangsang siswa untuk memperkuat dan mempercepat proses adaptasi agar dapat mengikuti pembelajaran dengan baik.

Motivasi merupakan hal yang sangat penting dalam proses belajar. Hal itu dikarenakan motivasi mempengaruhi siswa untuk melakukan hal tertentu secara intensif, memulai sesuatu dari diri sendiri dan bertahan saat menghadapi kesulitan. Motivasi belajar dapat membimbing menuju tujuan belajar, menumbuhkan sikap belajar, menguatkan kembali riwayat kognisi, dan meningkatkan hasil belajar. Uno menyatakan bahwa motivasi belajar merupakan dorongan internal dan eksternal siswa yang sedang dalam proses belajar untuk melakukan perubahan tingkah laku. Motivasi belajar tersebut dapat dilihat melalui beberapa indikator, yaitu adanya hasrat dan keinginan untuk berhasil, adanya dorongan dan kebutuhan dalam belajar, adanya harapan dan cita-cita masa depan, adanya penghargaan dalam belajar, adanya kegiatan yang menarik dalam belajar, dan adanya lingkungan belajar yang kondusif untuk siswa. Motivasi belajar pada siswa juga dapat dipengaruhi oleh beberapa faktor lain, seperti faktor lingkungan (kebersihan, cuaca, dan kondisi sekitar), suasana hati siswa, tingkat ketertarikan siswa, perilaku guru, kondisi ruang kelas, dan sebagainya.

Guru memegang peranan penting dalam merangsang motivasi belajar siswa. Guru harus sadar bahwa setiap kelas memiliki beberapa siswa yang termotivasi dan beberapa yang tidak, sehingga guru harus memahami dan menggunakan teknik spesifik untuk mengubah perilaku siswa agar berprestasi. Usaha untuk mengembangkan motivasi belajar siswa dapat dilakukan melalui manajemen kelas. Manajemen adalah serangkaian proses perencanaan, pengorganisasian, pengambilan keputusan, pengarahan, dan pengendalian yang berfokus pada pemanfaatan sumber daya untuk mencapai tujuan secara efektif dan efisien. Manajemen kelas adalah usaha-usaha untuk membangun dan mengelola kelas menjadi lingkungan belajar yang 
SHEs: Conference Series 3 (4) (2020) 126-131

efektif. Manajemen kelas merupakan proses untuk mengembangkan lingkungan belajar dan interaksi fisik, memotivasi siswa untuk belajar, serta mengelola kelas untuk memfasilitasi dan mendukung kesinambungan proses belajar mengajar dengan tujuan untuk meningkatkan kualitas dan prestasi siswa.

Untuk mengembangkan kelas yang kondusif, guru dapat menggunakan prinsip-prinsip manajemen kelas, yaitu membuat suasana kelas yang hangat dan antusias, menciptakan pembelajaran yang menantang, menggunakan variasi pembelajaran, menggunaan cara bertindak yang luwes, menanaman hal-hal positif kepada siswa, serta mengutamakan sikap guru di depan kelas yang membuat siswa menjadi pribadi yang patuh dikarenakan kekaguman dan kebanggaan terhadap guru. Selain itu, dalam pelaksanaan manajemen kelas yang baik terdapat prinsip-prinsip yang perlu diperhatikan sebagai berikut: sikap guru yang angat dan antusias, pembelajaran yang menantang, variasi pembelajaran, keluwesan guru dalam bertindak, penekanan hal positif pada siswa, dan penanaman kedisiplinan dalam setiap perilaku siswa.

Penelitian Sulaiman (2017) tentang motivasi dan pengelolaan suasana belajar melalui manajemen kelas menyatakan bahwa penerapan manajemen kelas berpengaruh positif terhadap kualitas interaksi di kelas dan memotivasi siswa untuk melakukan kegiatan belajar secara optimal. Sejalan dengan penelitian tersebut, Sa'adah dkk. (2013) yang meneliti tentang hubungan antara manajemen kelas dengan motivasi belajar siswa menyatakan bahwa terdapat hubungan yang kuat antara pelaksanaan pendekatan manajemen kelas dengan motivasi belajar. Selain itu, hasil penelitian Osakwe (2014) tentang manajemen kelas menunjukkan bahwa manajemen kelas yang efektif berpengaruh secara signifikan pada iklim belajar, motivasi siswa, disiplin, penghormatan siswa, pencapaian tujuan, dan prestasi belajar siswa. Berdasarkan uraian tersebut, dapat disimpulkan bahwa manajemen kelas mempunyai pengaruh yang positif dalam merangsang motivasi belajar siswa.

Penelitian ini bertujuan untuk mendeskripsikan penerapan prinsip manajemen kelas di SDN Mangunlegi 01 Batangan dan pengaruhnya terhadap motivasi belajar siswa. Penerapan prinsip manajemen kelas dapat menciptakan suasana kelas yang kondusif. Suasana kelas yang kondusif dapat merangsang timbulnya motivasi belajar siswa. Siswa dengan motivasi belajar dapat mengikuti proses pembelajaran secara maksimal, sehingga tujuan pembelajaran dapat tercapai secara optimal.

\section{METODE}

Penelitian ini merupakan penelitian kualitatif deskriptif yang dilaksanakan di SDN Mangunlegi Batangan selama 2 bulan, yaitu pada bulan Oktober - November 2020. Metode penelitian yang digunakan adalah metode deskriptif. Hal itu dikarenakan peneliti tidak melakukan kontrol dan manipulasi terhadap variabel yang diteliti. Dalam menganalisis masalah-masalah yang diteliti, peneliti menggunakan metode kualitatif. Metode kualitatif merupakan metode untuk meneliti obyek secara alamiah yang menempatkan peneliti sebagai instrumen kunci, teknik pengumpulan data menggunakan triangulasi (gabungan), analisis data bersifat induktif, dan hasil penelitian lebih menekankan pada makna dari pada generalisasi.

Pengumpulan data penelitian yang dilakukan peneliti menggunakan teknik wawancara, observasi, kuesioner, dan analisis dokumen. Partisipan yang menjadi sumber data penelitian adalah 1 guru kelas I dan 14 siswa yang merupakan siswa kelas 1. Data penelitian diuji validitasnya melalui uji kredibilitas, uji transferabilitas, uji dependabilitas, dan uji konfirmabilitas. Uji kredibilitas dilakukan peneliti menggunakan triangulasi teknik, yaitu dengan membandingkan data yang dikumpulkan melalui teknik yang berbeda, yaitu wawancara, observasi, kuesioner, dan analisis dokumen, sehingga data yang dihasilkan valid dan kredibel. Uji transferabilitas, dependabilitas, dan konfirmabilitas dilakukan secara bersamaan melalui proses konsultasi, pendampingan, dan pengujian oleh para ahli untuk memperoleh hasil penelitian yang valid dan terpercaya. 
SHEs: Conference Series 3 (4) (2020) 126-131

\section{HASIL DAN PEMBAHASAN}

Penerapan prinsip manajemen kelas di kelas 1 SDN Mangunlegi 01 Batangan terlaksana dengan baik. Prinsip-prinsip tersebut yaitu sikap guru yang antusias, hangat dan akrab, penciptaan pembelajaran yang menantang di kelas, variasi dalam pembejaran terkait teknik, pendekatan, serta media belajar, penggunaan cara yang luwes dalam setiap tindakan guru, penekanan hal positif pada perilaku siswa, serta penanaman kedisiplinan pada siswa. Penerapan prinsip manajemen kelas di SDN Mangunlegi 01 Batangan berpengaruh terhadap motivasi belajar siswa. Hal itu dikarenakan manajemen kelas menjadi variabel penentu adanya motivasi ekstrinsik di dalam kelas dan merangsang motivasi intrinsik siswa untuk belajar secara intensif. Motivasi belajar siswa dapat dilihat melalui beberapa indikator, yaitu adanya keaktifan siswa di kelas, kemauan siswa untuk mencoba hal sulit, keinginan siswa untuk berhasil, kemauan siswa untuk memulai proses belajar dari diri sendiri, bertahan saat meghadapi kesulitan, dan memperhatikan guru yang sedang mengajar.

Hangat, akrab, dan antusias erat kaitannya dengan sikap guru yang bersahabat. Guru yang akrab dan bersahabat, serta menghargai setiap pendapat dapat membuat siswa aktif di dalam kelas. Sikap guru yang hangat, akrab, dan antusias berpengaruh terhadap hubungan guru dengan siswa. Hubungan yang baik dapat menciptakan situasi kelas yang kondusif. Kondusivitas dapat membuat siswa termotivasi untuk berusaha, sehingga akan timbul kemauan untuk berhasil mencapai tujuan tertentu. Hal itu berpengaruh pada kemauan siswa untuk mecoba hal sulit dan berhasil melakukannya. Dikarenakan adanya kemauan, siswa yang mengalami kesulitan pun dapat bertahan hingga dapat berhasil. Lingkungan yang kondusif dapat meningkatkan rasa ingin tahu dan ketertarikan siswa. Rasa ingin tahu dan keteratrikan tersebut dapat membuat siswa fokus memperhatikan penjelasan guru dan memulai melakukan sesuatu tanpa disuruh, seperti bertanya dan berlatih menyelesaikan permasalahan terkait hal yang menarik tersebut.

Salah satu contoh keluwesan guru adalah kemampuan menerapkan variasi strategi belajar sesuai dengan kebutuhan. Kemampuan guru menerapkan strategi pembelajaran yang sesuai dapat menciptakan pembelajaran yang menarik dan menantang. Penguasaan dan penerapan variasi pembelajaran oleh guru dapat berpengaruh terhadap keaktivan siswa di kelas. Sangat penting untuk menerapkan metode pembelajaran yang bervariasi agar untuk menciptakan suasana belajar yang kondusif. Hal itu berpengaruh pada ketertarikan siswa yang secara langsung berpengaruh terhadap keaktifan siswa dalam mengikuti pembelajaran. Siswa yang aktif senantiasa memperhatikan guru untuk dapat memahami materi yang sedang pelajari. Salah satu variasi pembelajaran adalah dengan menggunakan metode eksperimen, yaitu pembelajaran yang melibatkan siswa dalam suatu percobaan. Hal itu dapat meningkatkan motivasi belajar siswa. Selain itu, dapat pula menggunakan metode Numbered Head Together (NHT) yang membuat pembelajaran menjadi aktif, kreatif, menyenangkan dan efisien, sehingga dapat merangsang motivasi belajar siswa, Permainan yang diselipkan dalam pembelajaran dapat pula menjadi variasi untuk meningkatkan motivasi dan prestasi belajar siswa.

Guru sebagai role model bagi siswa di sekolah memiliki kewajiban untuk mengajarkan tidak hanya pengetahuan, tetapi juga sikap-sikap positif pada siswa yang akan membentuk personality siswa. Melalui penekanan hal-hal positif, diharapkan dapat membentuk kepercayaan diri, jati diri, dan tanggung jawab siswa. Siswa yang telah terbentuk tanggung jawab dalam diri akan menjadi pribadi yang disiplin dalam mengikuti proses belajar. Kedisiplinan secara umum meliputi kepatuhan, kesabaran, ketertiban, kemauan mengikuti guru dan kemauan untuk menyelesaikan tugas. Siswa yang disiplin akan senantiasa fokus mencapai tujuan belajar, memperhatikan guru, mengatur waktu dengan baik, berusaha lebih keras, dan menunjukkan tekad yang kuat untuk berhasil dalam belajar. Berdasarkan hal tersebut, maka sangat penting bagi guru untuk menanamkan kedisiplinan pada siswa. Manajemen kelas di SDN Mangunlegi 01 Batangan terlaksana dengan baik sesuai dengan prinsip- prinsip manajemen kelas, yaitu sikap guru yang 
SHEs: Conference Series 3 (4) (2020) 126-131

antusias, hangat dan akrab, pembelajaran yang menantang, variasi pembelajaran, keluawesan dalam setiap tindakan guru, penekanan hal-hal positif, dan penanaman kedisiplnan siswa. Melalui penerapan manajemen kelas, pembelajaran yang terlaksana menjadi lebih kondusif, efektif, dan efisien. Penerapan prinsip manajemen kelas berpengaruh terhadap timbulnya motivasi belajar siswa. Suasana yang kondusif mendorong rasa nyaman bagi siswa, sehingga siswa termotivasi untuk mengikuti proses belajar dengan senang hati. Motivasi belajar siswa dapat dilihat melalui beberapa indikator, yaitu aktif dalam pembelajaran, memiliki keinginan untuk berhasil, memiliki kemauan untuk memulai dari diri sendiri, bertahan saat menghadapi kesulitan, dan memperhatikan apa yang diajarkan guru. Implikasi teoritis pada penelitian ini yaitu penerapan prinsip manajemen kelas dapat menciptakan suasana kelas yang kondusif dan mendukung proses pembelajaran, sehingga dapat berpengaruh pada tingginya motivasi belajar siswa di kelas. Selain itu, implikasi praktis pada penelitian ini yaitu hasil penelitian dapat digunakan sebagai masukan bagi guru dalam mengelola kelas menggunakan prinsip manajemen kelas, sehingga tercipta pembelajaran yang efektif dan efisian serta mendukung tercapainya tujuan pembelajaran.

\section{SIMPULAN}

Manajemen kelas di SDN Mangunlegi 01 Batangan terlaksana dengan baik sesuai dengan prinsip- prinsip manajemen kelas, yaitu sikap guru yang antusias, hangat dan akrab, pembelajaran yang menantang, variasi pembelajaran, keluawesan dalam setiap tindakan guru, penekanan hal-hal positif, dan penanaman kedisiplnan siswa. Melalui penerapan manajemen kelas, pembelajaran yang terlaksana menjadi lebih kondusif, efektif, dan efisien. Penerapan prinsip manajemen kelas berpengaruh terhadap timbulnya motivasi belajar siswa. Suasana yang kondusif mendorong rasa nyaman bagi siswa, sehingga siswa termotivasi untuk mengikuti proses belajar dengan senang hati. Motivasi belajar siswa dapat dilihat melalui beberapa indikator, yaitu aktif dalam pembelajaran, memiliki keinginan untuk berhasil, memiliki kemauan untuk memulai dari diri sendiri, bertahan saat menghadapi kesulitan, dan memperhatikan apa yang diajarkan guru. Implikasi teoritis pada penelitian ini yaitu penerapan prinsip manajemen kelas dapat menciptakan suasana kelas yang kondusif dan mendukung proses pembelajaran, sehingga dapat berpengaruh pada tingginya motivasi belajar siswa di kelas. Selain itu, implikasi praktis pada penelitian ini yaitu hasil penelitian dapat digunakan sebagai masukan bagi guru dalam mengelola kelas menggunakan prinsip manajemen kelas, sehingga tercipta pembelajaran yang efektif dan efisian serta mendukung tercapainya tujuan pembelajaran.

\section{DAFTAR PUSTAKA}

Sari, B P, Hadijah, H S 2017 Meningkatkan Disiplin Belajar Siswa melalui Manajemen Kelas," J. Pendidik. Manaj. Perkantoran, 2(2) 122

Shabani, K 2012 Dynamic Assessment of L2 Learners' Reading Comprehension Processes: AVygotskian Perspective Procedia Soc. Behav. Sci., 32 321-328

Uno, H B 2016 Teori Motivasi dan Pengukurannya (Jakarta: Bumi Aksara)

Sunu, I G K A 2015 Manajemen Kelas: Aplikasinya dalam Proses Pembelajaran di Pendidikan Formal (Yogyakarta: Media Akademi)

Sa'adah, A., Supriyanto, A., Maisyaroh 2013 Hubungan Pendekatan Manajemen Kelas dengan Motivasi Belajar Siswa Manaj. Pendidik 24 108-113

Sudaryono 2017 Metodologi Penelitian (Jakarta: Rajawali Press)

Sugiyono, 2016 Metode Penelitian Pendidikan (Pendekatan Kuantitatif, Kualitatif, dan $R \& D)($ Bandung: Alfabeta)

Zulaekho, S 2020 Penggunaan Metode Eksperimen untuk Meningkatkan Motivasi Belajar IPA pada Tema Peristiwa dalam Kehidupan bagi Siswa Kelas VA SD Negeri 2 Leteh, Kecamatan Rembang, Kabupaten Rembang J. Pendidik. Dasar 8(1) 
Febrianti, A. W 2020 Penerapan Model Pembelajaran Numbered Head Together (NHT) untuk Meningkatkan Motivasi Belajar dalam Pembelajaran IPS pada Peserta Didik Kelas IV Sekolah Dasar Didakt. Dwija Indria 8(3)

Suwarti, T 2019 Upaya Peningkatan Motivasi Belajar Lari Jarak Pendek melalui MetodeBermain pada Siswa Kelas V Sekolah Dasar JPI (Jurnal Pendidik. Indones. J. IIm. Pendidik., 5(1) 162-169 